\title{
Maternal UPD 20 in a hyperactive child with severe growth retardation
}

\author{
I Chudoba ${ }^{1}$, Y Franke ${ }^{2}$, G Senger ${ }^{1}$, G Sauerbrei ${ }^{4}$, S D emuth $^{3}, \mathrm{~V}$ Beensen ${ }^{1}, \mathrm{~A}$ N eumann ${ }^{1}$, \\ I $\mathrm{H}_{\text {ansmann }}{ }^{2}$ and $\mathrm{U}$ Claussen $^{1}$ \\ ${ }^{1}$ Institute of H uman $\mathrm{G}$ enetics and A nthropology, Friedrich-Schiller-U niversity, Jena \\ ${ }^{2}$ Institute of H uman $\mathrm{G}$ enetics and M edical Biology, M artin-L uther-U niversity, $\mathrm{H}$ alle \\ ${ }^{3} \mathrm{G}$ enetic Counselling Service, E rfurt \\ ${ }^{4} \mathrm{C}$ hildrens and A dolescence $\mathrm{H}$ ospital, E rfurt, G ermany
}

\begin{abstract}
M aternal uniparental disomy was observed in a 4-year-old boy with severe pre- and postnatal growth retardation (body height: $85 \mathrm{~cm}=12 \mathrm{~cm}$ < third percentile, head circumference: $48 \mathrm{~cm}=10 \mathrm{~cm}<$ third percentile), a few minor facial findings, and with apparent hyperactivity. $H$ is intelligence is within the normal range for his age. $K$ aryotype analysis revealed two cell lines, one apparently normal with $46, X Y$, the other with a tiny marker $(47, X Y,+$ mar).

Microdissection and reverse chromosome painting using the marker D NA library as a probe, as well as PCR analysis revealed that the marker is from chromosome 20 and contains only the centromere and pericentromeric segments, but none of the pericentromeric loci for microsatellites. Microsatellite analysis of 25 chromosome 20 loci disclosed maternal uniparental disomy for all 16 informative markers. M aternal heterodisomy was evident for seven loci of the short arm segment 20p11.2-pter. M aternal isodisomy was found at five loci, three of them map to the proximal 20p11.2 segment and two to 20q. To our knowledge, this is the first case of maternal disomy 20 in humans.
\end{abstract}

Keywords: unimaternal disomy 20; microdissection; marker chromosome; reverse painting; microsatellite analysis

\section{Introduction}

U niparental disomy (UPD) is a condition in which a chromosomally disomic individual inherited both copies of a chromosome from one parent only. ${ }^{1}$ D epending on the identity of both chromosome homologues, U PD is defined as either heterodisomy (inheritance of both homologues from one parent) or isodisomy (presence of two identical copies of one homologue). UPD is associated with advanced maternal age, implying that it

Correspondence: Professor Dr U Claussen, Institute of Human Genetics and Anthropology, Kollegiengasse 10; D -07740 Jena, G ermany

R eceived 30 July 1998; revised 190 ctober 1998; accepted 23 O ctober 1998 is frequently derived from meiotic nondisjunction followed by rescue of trisomic or monosomic conceptuses. ${ }^{2} \mathrm{~A}$ bnormal phenotypes in U PD are explained by the detrimental effect of the lack of a normal homologue to an imprinted gene, homozygosity for recessive genes in case of isodisomy or partial isodisomy, ${ }^{3}$ and confined placental mosaicism with trisomy and/or monosomy. U PD has already been reported for more than two-thirds of human chromosomes. ${ }^{2,4}$

Pure U PD for chromosome 20 has not been known previously. This is surprising as mosaic trisomy 20 is observed rather frequently in prenatal diagnosis and is found in about $6 \%$ of amniotic fluid cell cultures. ${ }^{5}$ However, children born thereafter are almost always normal, and the trisomy 20 cell clone is thought to 
2-5. He was reported to be a friendly and hyperactive child with a high-pitched voice. $\mathrm{H}$ is IQ of 97 (K ramer-test) was within the normal range for his age. $\mathrm{H}$ is neurologic and motor development were normal.

\section{Cytogenetics}

Cytogenetic examination was carried out on peripheral blood of the patient as well as on his parents and mentally retarded sister. Chromosome harvesting followed standard techniques and karyotyping was performed after GTG and CBG banding.

\section{Microdissection}

Microdissection was carried out as described by Senger et al. ${ }^{7}$ Five marker chromosomes were excised under microscopical view using extended glass needles (inverted microscope IM 135, Z eiss, micromanipulator M R mot, Zeiss).

In order to gain information about the possible involvement of euchromatic material deriving either from the short or the long arm of chromosome 20, 20p and 20q specific microdissection libraries were generated. Five $p$-arms and five q-arms of chromosome 20 were collected in the same manner as the marker chromosome.

\section{DOP-PCR}

A mplification of the dissected chromosomal material was carried after protein digestion with Proteinase $\mathrm{K}$ ( 2 hours at $60^{\circ} \mathrm{C}$ ) according to a procedure described in previous research. ${ }^{8-10}$

only one report on a phenotypically severely affected child with paternal UPD 20, which was found in addition to mosaicism for trisomy 20 in several tissues. ${ }^{6}$ The second cell line had a dicentric chromosome due to an end-to-end short arm translocation of two paternal chromosome 20 homologues.

H ere we report on the first case of maternal U PD 20 in a proband with severe pre- and postnatal growth retardation and hyperactivity.

\section{Materials and Methods}

\section{Clinical information}

The male patient (Figure 1) was referred for cytogenetic investigation because of growth retardation and minor dysmorphic facial features. The pregnancy ended by section at 32 weeks of gestation because of a cervix carcinoma in the mother. A t time of conception the mother was 40-years-old. The pregnancy was normal until 30 weeks of gestation, when ultrasound showed that growth had decreased (birth weight: $1420 \mathrm{~g}$ and body length: $40 \mathrm{~cm}$ ). It was the mother's sixth pregnancy.

A t the age of 4 years and 2 months, the patient's height was $85 \mathrm{~cm}$ and his head circumference was $48 \mathrm{~cm}$ (both < third percentile). $\mathrm{H}$ is face showed a prominent supra orbital region, a relatively short philtrum, a thin upper lip, a high palate and relatively large, slightly dysmorphic, backward rotated ears. Furthermore, he had hyperextensible wrist joints and fingers and partial soft tissue syndactyly of the fingers

\section{Fluorescence in situ hybridisation (FISH)}

For FISH experiments, amplified DNA from the marker chromosome and the $20 \mathrm{q}$ library were labelled with Biotin16-dUTP, the 20p library with Digoxigenin-11-dUTP. ${ }^{11}$ Hybridisation was performed following standard procedures. $^{12}$ In reverse painting experiments on replication $\mathrm{G}$-banded chromosomes, the biotinylated probe derived from the marker was detected with A vidin-Texas Red (Vector laboratories). Chromosome banding was obtained by incorporating $\mathrm{BrdU}$ into the late S-phase after synchronisation with Methotrexate. ${ }^{13} \mathrm{~A}$ replication banding comparable to $\mathrm{G}$-bands was obtained by incubation with FITC conjugated anti-B rdU. Slides were mounted in antifade solution (Vectashield) containing DA PI as a counterstain.

Slides were analysed using a Z eiss A xioskop microscope (Carl Z eiss Jena, Germany) equipped with a Pinkel \#l filter set (Chroma Technologies). Images were captured and processed using a standard integrating CCD video camera (Sony) and the isis software package (M etaSystems, A Itlussheim, G ermany).

\section{Radioactive PCR}

Genomic DNA was isolated from nucleated blood cells. The CA strand oligodesoxynucleotide primers were end-labelled for $30 \mathrm{~min}$ at $37^{\circ} \mathrm{C}$ in a $7 \mu \mathrm{l}$ reaction containing $500 \mathrm{ng}$ primer, $70 \mathrm{~mm}$ Tris ( $\mathrm{pH} 7.6), 10 \mathrm{~mm} \mathrm{M} \mathrm{gCl} 2,5 \mathrm{~mm}$ DTT, 7 units T4 polynucleotide kinase (New England Biolabs), and $1.25 \mu \mathrm{Ci} \mathrm{g}{ }^{32} \mathrm{P}-\mathrm{dATP}$ at $3000 \mathrm{Ci} / \mathrm{mmol}$. R eactions were stopped by incubation at $95^{\circ} \mathrm{C}$ for $2 \mathrm{~min}$. Polymerase chain reactions 
were carried out in $25 \mu \mathrm{l}$ volumes containing $100 \mathrm{ng}$ of endlabelled primer, $100 \mathrm{ng}$ of each unlabelled primer, $100 \mathrm{ng}$ of genomic DNA template, $200 \mu \mathrm{M}$ each dGTP, dCTP, dATP, and dTTP, $50 \mathrm{~mm} \mathrm{KCl}, 10 \mathrm{~mm}$ Tris ( $\mathrm{pH} 8.3), 1.5 \mathrm{~mm} \mathrm{M} \mathrm{gCl} 2$ and 0.5 units Taq polymerase (B oehringer, $M$ annheim).

A mplification conditions were 1 min denaturation at $94^{\circ} \mathrm{C}$, $1 \mathrm{~min}$ annealing at $55^{\circ} \mathrm{C}$ and $2 \mathrm{~min}$ extension at $72^{\circ} \mathrm{C}$ for 30 cycles. The last elongation step was lengthened to $7 \mathrm{~min}$. A liquots of the amplified DNA were mixed with 1 vol formamide sample buffer and were analysed on $8 \%$ denaturing polyacrylamide gels. G els were then fixed and exposed to autoradiograph film for $1 \mathrm{~d}$.

L oci used for PCR include D20S113, D 20S199, D 20S189, D 20S98, D 20S104, D20S114, D 20S184, D 20S103, D 20S192, D 20S188, D 20S66, D 20S112, and D 20S195; ${ }^{14}$ D 20S59, D 20S41，D 20S50，D 20S64; ${ }^{15}$ D 20S175，D 20S186，D 20S119, D 20S102, and D 20S100; ${ }^{16}$ D 20S17; ${ }^{17}$ U T246; ${ }^{18}$ D 20S27; ${ }^{19}$ 1H 5-CA (Giannakudis, pers. com.); and F2B 6-CA (Franke, unpublished)

\section{Results}

Cytogenetic analysis of 50 metaphases from blood lymphocytes revealed a karyotype of $46, X Y$ (28)/47, XY, + mar(20). The small marker chromosome represents approx. twenty per cent of the length of chromosome 21q (Figure 2). A ccording to CBG-banding it consists entirely of constitutive heterochromatin. Under the light microscope, there is no evidence of

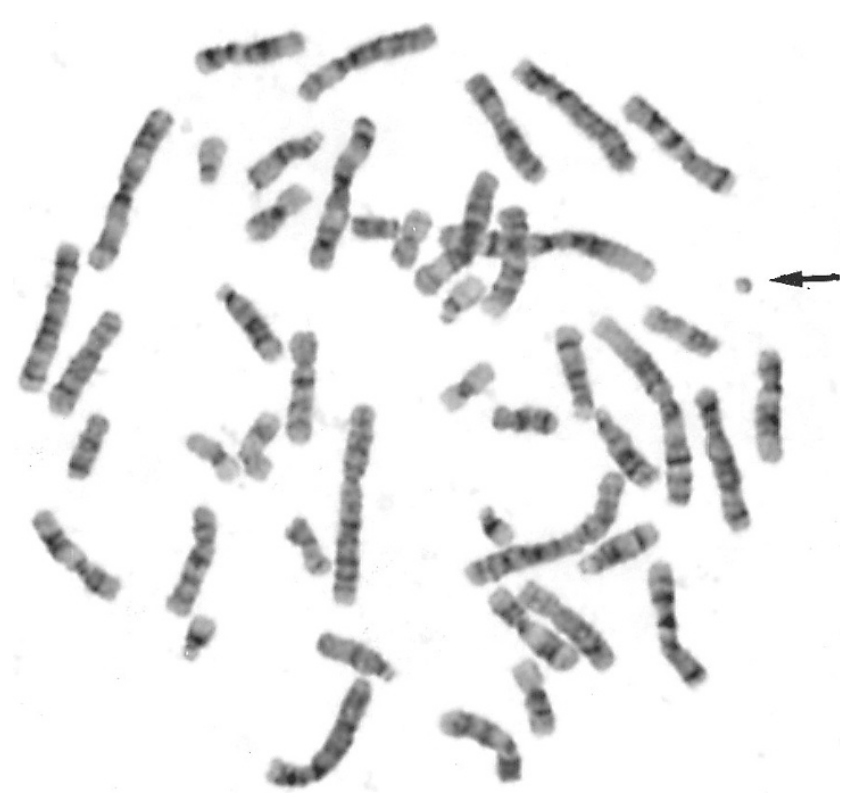

Figure 2 Representative GTG-banded metaphase spread from the patient, containing the marker chromosome $(\leftrightarrow)$ pericentromeric G-band negative material. Parental karyotypes and the karyotype of the sister were normal in 50 metaphases analysed from each.

Fluorescence in situ hybridisation (FISH) on normal metaphases from a control using the marker-specific microdissection library (reverse chromosome painting) revealed signals exclusively at the centromeres of both chromosomes 20, indicating its chromosome 20 origin. Reverse painting on metaphases from the proband revealed only two signals at the centromere of both normal chromosomes 20 in $46, X Y$ cells but three signals (centromere of both chromosomes 20 and the marker) in $47, X Y,+$ mar. The FISH signals on the marker appeared considerably brighter in comparison to the signals on both chromosomes 20 and covered the marker completely (Figure $3 \mathrm{~A}$ and $\mathrm{B}$ ).

The chromosome 20p- and 20q-specific microdissection probes were labelled differentially, hybridised to metaphase spreads of the proband and were analysed by two-colour FISH, with one colour for each arm, respectively. The two normal chromosomes 20 were clearly identified by differentially stained $p$ - and q-arms, while no FISH signal were detected on the small marker (not shown).

A ltogether, 25 highly polymorphic microsatellite markers for chromosome 20 were studied in this family by radioactive $P C R$. R esults of genotyping are given in Table 1, where markers are listed according to the most likely order within the physical/genetic map (NCBI, genomes data base, release 3.8). A n exclusively maternal inheritance was disclosed at 16 loci (see Table 1 ), the remaining nine loci are considered to be noninformative with respect to the segregation of alleles in the family.

Proband and mother share identical heterozygous alleles at seven loci (D 20S113, D 20S199, D 20S189, 1H 5, D 20S41, U T246, D20S98). A t each of these loci, the father is heterozygous for different alleles, thus revealing maternal heterodisomy. Maternal isodisomy was found at five loci (D 20S104, D 20S114, D 20S184, D 20S17, D 20S119). Three of them (D 20S104, D 20S114, D 20S184) map to the proximal third of the short arm. A t four additional loci (D20S59, D20S195, D 20S173, D 20S64) mother and proband are homozygous for the same allele, while the father is heterozygous for two different alleles.

DNA of the microdissected and DOP-amplified marker was further used as template to narrow down the molecular content of the marker chromosome and, eventually, for identifying its parental origin. None of 
revealed any signal derived from that marker (data not shown).
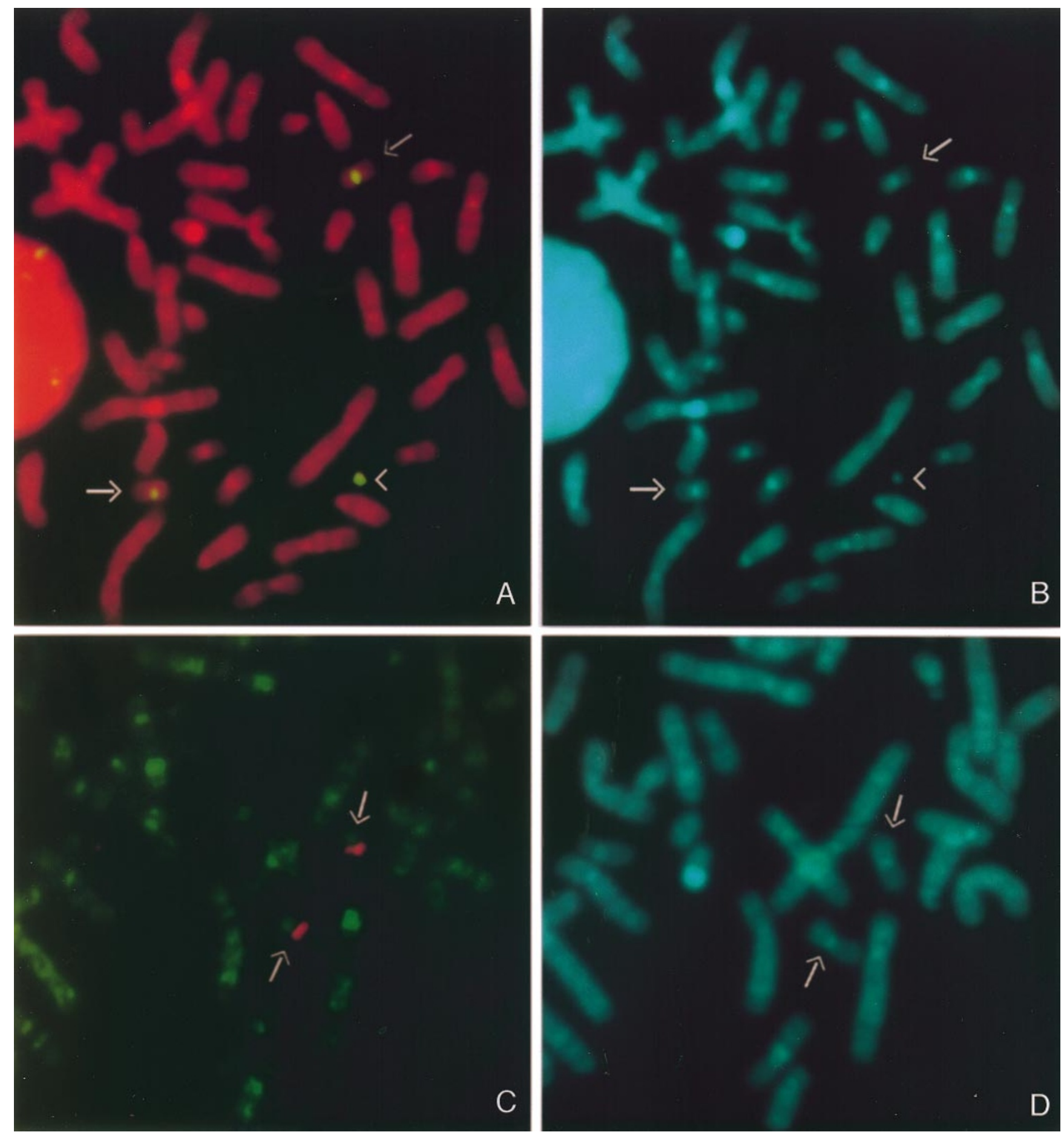

Figure $3 \mathrm{~A}+\mathrm{B}) \mathrm{FISH}$ of the microdissection library to metaphase spreads of the patient containing the marker chromosome Fluorescent signals are observed in the centromeric region of both chromosomes $20(\rightarrow)$ and on the marker chromosome $(<)$. C + D ) FISH of the microdissection library to normal metaphase spreads. A replication banding pattern corresponding to $\mathrm{G}$-bands identifies the chromosomes indicated by the fluorescent signals as chromosome 20. 


\section{Discussion}

A ccording to our FISH and microsatellite analysis, the marker of our proband comprises mainly the centromere of chromosome 20p and its pericentromeric heterochromatin. The presence of 20p and/or 20 specific DNA was examined using the respective arm-specific microdissection libraries. No FISH signal was revealed with any of them at the marker. The absence of FISH signals could have been due to technical limits, eg euchromatic DNA close to the centromere is not contained in the library or the amount of euchromatic pericentromeric DNA of the marker is too small to be detected by FISH. N evertheless, these results suggest that pericentromeric euchromatin should only be a minor component of that marker, if present at all. This is confirmed by the analysis of pericentromeric microsatellites (eg D 20S184, D 20S195, D 20S493). Trisomy was observed for none of these loci when genomic

Table 1 Results of microsatellite analysis for chromosome 20 in the proband and his parents (ni: noninformative; matiso: maternal isodisomy; mat-hetero: maternal heterodisomy; mat: maternal alleles only)

\begin{tabular}{lcccc}
\hline M arker & Father & Proband & M other & origin of alleles \\
\hline 20p: & & & & \\
D 20S103 & aa & ab & ab & ni \\
D 20S192 & ab & aa & aa & ni \\
D 20S113 & cc & ab & ab & mat-hetero \\
D 20S199 & ad & bc & bc & mat-hetero \\
D 20S59 & ac & bb & bb & mat \\
D 20S175 & ab & ab & ab & ni \\
D 20S188 & ab & ac & ac & ni \\
D 20S189 & bd & ac & ac & mat-hetero \\
D 20S186 & bc & ab & ab & ni \\
D 20S27 & aa & ab & ab & ni \\
1H 5 & ad & bc & bc & mat-hetero \\
F2 2 6 & aa & ab & ab & ni \\
D 20S41 & ab & cd & cd & mat-hetero \\
U 246 & bc & ad & ad & mat-hetero \\
D 20S98 & ad & bc & bc & mat-hetero \\
D 20S104 & ac & cc & bc & mat-iso \\
D 20S114 & bd & aa & ab & mat-iso \\
D 20S184 & bb & aa & ab & mat-iso \\
D 20S493 & aa & aa & aa & ni \\
centromere & & & & \\
20q: & & & & \\
D 20S195 & cd & aa & aa & mat \\
D 20S17 & ab & cc & ac & mat-iso \\
D 20S119 & bc & dd & ad & mat-iso \\
D 20S173 & aa & bb & bb & mat \\
D 20S102 & bb & bb & bb & ni \\
D 20S64 & bb & aa & aa & mat \\
\hline
\end{tabular}

DNA was used as template. Furthermore, no allele was detected by PCR using microdissected and DOPamplified marker DNA. From these data it is unlikely that the marker is causally related to the phenotype and hyperactivity of the proband, but they do not exclude the possibility that the marker contains one or a few genes that cause the proband's phenotype.

M icrosatellite analysis revealed maternal U PD 20 at all 16 informative loci. To our knowledge this proband represents the first case of maternal UPD for chromosome 20 . M aternal heterodisomy was only observed for loci of the distal segment of 20p, including the proximal locus for D 20S98, which has been mapped to 20p11.2 (unpublished observations). For three proximal 20p loci and two loci on 20q, genotyping revealed maternal isodisomy. The combination of two segments with heterodisomy and isodisomy can be explained by one recombination event between D20S98 and D 20S104. B ecause that recombination creates partial isodisomy it cannot be decided whether maternal UPD of chromosome 20 is due to a meiosis I or meiosis II error. A meiosis II error, however, seems to be more likely as the patient has isodisomy at D20S184 in 20p and D $20 S 17$ at 20q. Both markers are close to the centromere, where recombinations are exceedingly rare. The karyotype of our proband is $47, X Y,+$ mar.rev ish $\operatorname{der}(20)(: p 11.2$ Û q11.2:)/46,XY.

The question now is whether the severe prenatal and postnatal growth retardation of our proband is due to maternal UPD and imprinting, homozygosity for recessive genes within the isodisomic segment, or whether it is associated with placenta failure because of confined placental trisomy 20. A partial trisomy effect of the small marker is rather unlikely, due to the results obtained by FISH and microsatellites described above. A phenotypic effect of maternal UPD 20 on prenatal and postnatal growth is not unlikely, taking into account data from the literature where several cases with maternal UPD and growth retardation have been reported, such as for chromosome $7^{21-24}$ and chromosome $16{ }^{25,26}$ Maternal UPD for chromosome 16 was also detected in cases in which a trisomy 16 placental karyotype was identified in chorionic villi during prenatal diagnosis. In these cases one cannot clearly distinguish between a maternal UPD effect and placental insufficency due to confined placental mosaicism for trisomy 16. In none of these cases was a postnatal follow up possible. Two pregnancies ended as spontaneous abortion ${ }^{25}$ and one infant died 140 days post partum. ${ }^{26}$ Intrauterine growth retardation in our case 
was detected at 30 weeks of gestation. A t the age of four years our proband is still extremely small for his age and so far he has not caught up on his growth retardation. It is not unlikely, therefore, that his prenatal and postnatal growth retardation is due to maternal UPD and imprinting or due to homozygosity of one or several recessive gene(s).

$G$ enetic studies in mice have led to the definition of 15 imprinting effects including retarded growth and behavioural abnormalities. ${ }^{27}$ Two of them have been associated with a distal region of mouse chromosome 2 , which shows homology with human chromosome $20 .^{28,29}$ Here, paternal UPD of this region led to hyperactivity and a short and broad body shape. Maternal UPD instead resulted in a counter type, totally inactive mice with a long and flat body. In contrast to the effects of UPD in mice, our case of maternal UPD 20 is associated with hyperactivity and not with inactivity as could have been expected from observations with the respective maternal UPD 2 mice. Even though the paternal origin of UPD in the hyperactive mice does not match our case, it is likely that the hyperactive behaviour of the boy is due to a maternal imprinting effect. Hyperactivity is not known in other members of the family.

Several mechanisms have been reported resulting in U PD. They are regarded as mechanisms for aneuploidy correction and include gamete complementation, monosomy duplication and 'trisomy rescue'. $., 4,30$ 'Trisomy rescue' is well documented for cases with confined placental trisomy 16 and uniparental disomy in the foetus ${ }^{31}$ as well as for cases with Prader Willi Syndrome

$\begin{array}{lllllllll}\text { JH } & \text { PH } & \text { EH } & \text { JH } & \text { PH } & \text { EH } & \text { JH } & \text { PH } & \text { EH } \\ \text { ad } & \text { bc } & \text { bc } & \text { bc } & \text { ad } & \text { ad } & \text { ac } & \text { cc } & \text { bc }\end{array}$

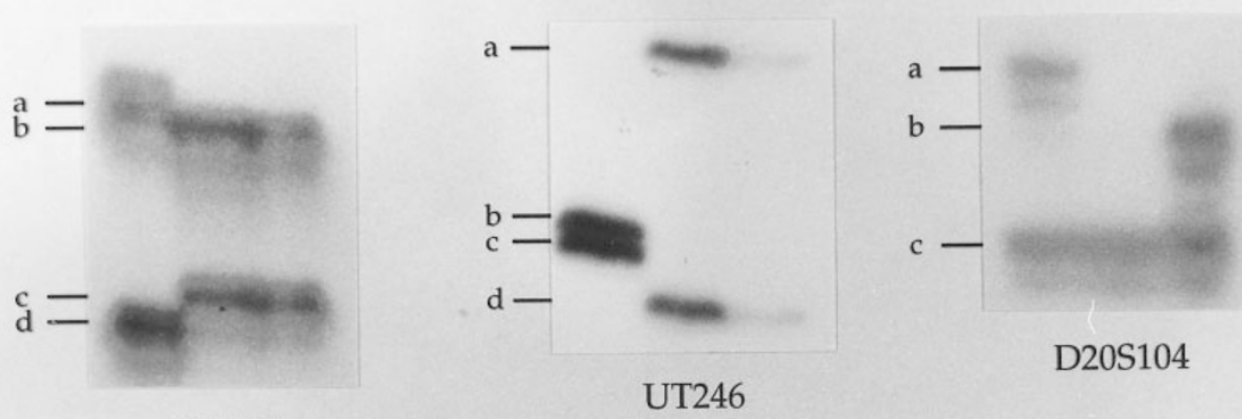

1H5-CA

JH PH EH

bd aa ac

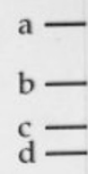

$\begin{array}{llll}\mathrm{JH} & \mathrm{PH} & \mathrm{EH}\end{array}$

$\mathrm{ab} \quad \mathrm{cc}$ ac

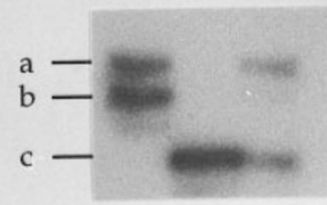

D20S17
JH $\quad$ PH $\quad \mathrm{EH}$

bb aa aa

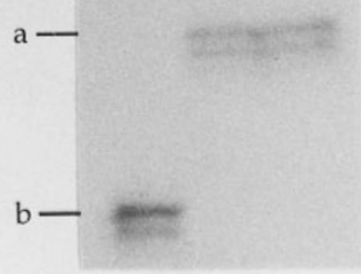

D20S64

Figure 4 Results of microsatellite analysis for 1H 5, UT246, D 20S104, D 20S114, D 20517 and D 20 S64 in the proband (PH), father $(\mathrm{JH})$ and mother $(\mathrm{EH})$. Maternal heterodisomy is shown for 1H5, UT246 and maternal isodisomy for D 20S104, D 20S114 and D 20S17. At D 20S64, both mother and proband are homozygous for aa with absence of the paternal allele in the proband (noninformative maternal UPD) 
(PWS) and maternal disomy. ${ }^{32} \mathrm{~A}$ nother probable example of incorrect 'trisomy rescue' comes from a case with PW S and a supernumerary marker chromosome 15 and maternal heterodisomy for that chromosome. ${ }^{33}$ A similar mechanism can be assumed for the present case. UPD resulting from nondisjunction and related to advanced maternal age has been reported in the literature. ${ }^{2}$ In our case it is also very likely that the zygote was trisomic for chromosome 20, with two chromosomes derived from the mother who was 40 years at conception of the proband and that breakage of the paternal chromosome subsequently. The DNA of the proband may help to identify imprinted genes on chromosome 20.

\section{Acknowledgements}

We gratefully acknowledge the financial support of $\mathrm{C}$ arl Zeiss J ena $\mathrm{G} \mathrm{mbH}$ for the colour printing. We thank $\mathrm{O}$ onagh Heron for helpful discussions.

\section{References}

1 Engel E: A new genetic concept: uniparental disomy and its potential effect, isodisomy. Am J M ed Genet 1980; 6: 137-143.

2 Ledbetter DH, E ngel E : U niparental disomy in humans: development of an imprinting map and its implications for prenatal diagnosis. H um M ol G enet 1995; 4: 1757-1764.

3 Pulkkinen L, Bullrich F, Czarnecki P, Weiss L, U itto J: $M$ aternal uniparental disomy of chromosome 1 with reduction to homozygosity of the LAMB 3 locus in a patient with $\mathrm{H}$ erlitz junctional epidermolysis bullosa. A m J H um G enet 1997; 61: 611-619.

4 Engel E: U niparental disomy revisited: the first twelve Y ears. A m J M ed G enet 1993; 46: 670-674.

$5 \mathrm{Hsu} \mathrm{L}, \mathrm{K}$ affe S, Perlis TE: A revisit of trisomy 20 mosaicism in prenatal diagnosis - an overview of 103 cases. Prenat-D iagn 1991; 11: 7-15.

6 Spinner NB, R and E, B ucan M, J irik R , Gogolin-E wens C, $R$ iethman $H C, M C D$ onald-M CG inn DM, Zackai $E H$ : Paternal uniparental isodisomy for human chromosome 20 and absence of external ears. A m J H um G enet 1994; 55: A 118 (A bstract).

7 Senger G, Lüdecke HJ, Horsthemke B, Claussen U: $\mathrm{M}$ icrodissection of banded human chromosomes. Hum Genet 1990; 84: 507-511.

8 Telenius H, Carter N P, B ebb CE, Nordenskjold M, Ponder $B A$, Tunnacliffe A: Degenerate oligonucleotide-primed PCR: general amplification of target DNA by a single degenerate primer. G enomics 1992; 13: 718-725.
9 R ubtsov N, Senger G, Kuzcera H, Neumann A, K elbova $C$, J unker $K, B$ eensen $V$, Claussen $U$ : Interstitial deletion of chromosome 6q: report of a case and precise definition of the breakpoints by microdissection and reverse painting. $\mathrm{H}$ um $\mathrm{G}$ enet 1996; 97: 705-709.

10 Chudoba I, Rubtsov N, Senger G, Junker K, Bleck C Claussen $U$ : Improved detection of chromosome 16 rearrangements in acute myeloid leukemias using $16 p$ and $16 q$ specific microdissection DNA libraries. Oncology Report 1996; 3: 829-832.

11 Pinkel D, Staume T, G ray J W: Cytogenetic analysis using quantative, high-resolution fluorescence hybridization. Proc Natl A cad Sci USA 1986; 83: 2934.

12 Kallionemi $O-P, K$ allionemi $A$, Kurisu W, Thor $A$, Chen $L-C$, Smith H S, Waldman F M , Pinkel D, G ray J W: E R B B 2 amplification in breast cancer analyzed by fluorescence in situ hybridization. Proc Natl Acad Sci USA 1992; 89: 5321.

13 Y unis J J: C hromosomal rearrangements, gene, and fragile sites in cancer: clinical and biological implications. In D evita VT, Hellman S, R osenberg SA (eds). Important advances in oncology. JB Lippincott: Philadelphia, 1986,pp 93-123.

14 G yapay G, M orissette J, Vignal A, Dib C, Fizames C, $M$ illasseau $P, M$ arc $S, B$ ernadi $G$, L athrop $M$, Weissenbach J: The 1993-1994 Genethon human linkage map. Nat G enet 1994; 7: 246-339.

15 Hazan J, Dubay C, Pankowiak M P, Becuwe N, Weissenbach J: A genetic linkage map of human chromosome 20 composed entirely of microsatellite markers. Genomics 1992; 12: 183-189.

16 Weissenbach J, G yapay G, D ib C, Vignal A, M orissette J, M illasseau $P$, Vaysseiz $G$, L athrop $M$ : A second generation linkage map of the human genome. Nature 1992; 359 794-801.

17 R othschild CB, A kots G, H ayworth R, Pettenati MJ, R ao PN, Wood P, Stolz FM, H ansmann I, Serino K, K eith TP, Fajans SS, Bowden DW: A genetic map of chromosome 20q12-q13.1: Multiple highly polymorphic microsatellite and R FLP markers linked to the maturity-onset diabetes of the young (M ODY) locus. A m J H um G enet 1993; 52 $110-123$.

18 M elis R, B radley P, E Isner T, R obertson M, L awrence E Gerken S, Albertsen $\mathrm{H}$, White R: Polymorphic SSR (simple-sequence-repeat) markers for chromosome 20 G enomics 1993; 16: 56-62.

19 Weber J L, M ay PE : D inucleotide repeat polymorphism at the D $20 S 27$ locus. Nucl A cids Res 1990; 18: 2202.

20 Callen D F, R ingenbergs M L, Fowler J CS, Freemantel CJ, $\mathrm{H}$ aan $\mathrm{EA}$ : Small marker chromosomes in man: origin from pericentric heterochromatin of chromosomes 1,9 and 16. J M ed G enet 1990; 27: 155-159.

21 Spence JE, Perciaccante RG, Greig GM, Willard HF, L edbetter DH, Heitmancik JF, Pollak MS, O'B rien WE, Beaudet $A L$ : U niparental disomy as a mechanism for human genetic disease. Am J Hum Genet 1988; 42: 217-226.

22 Voss R, B en-Simon E, A vital A, G odfrey S, Zlotogora J, Dagan J, Tikochinsky Y, H illel J: I sodisomy for chromosome 7 in a patient with cystic fibrosis: could uniparental disomy be common in humans? A m J H um G enet 1989, 45: $373-380$. 
23 Spotila LD, Sereda L, Prockop DJ : Partial isodisomy for maternal chromosome 7 and short stature in an individual with mutation COLIA 2 locus. A m J H um G enet 1992; 51: 1396-1405.

24 K otzot D, Schmitt S, B ernasconi F, R obinson W P, L urie I W, Ilyina $H$, M éhes $K, H$ amel $B C$ J, $O$ tten $B J$, H egersberg $M$, Werder $E$, Schoenle $E$, Schinzel A : U niparental disomy in Silver R ussel syndrome and primordial growth retardation. $\mathrm{H}$ um $\mathrm{M}$ ol $\mathrm{G}$ enet 1995; 4: 583-587.

25 Vaughan J, Z ehra A, B ower S, B ennett P, Chard T, M oore $\mathrm{G}$ : H uman maternal uniparental disomy for chromosome 16 and fetal development. Prenat Diagn 1994; 14: 751-756.

26 Whiteford M L, C outts J, A I-R oomi L, M ather A, L owther G, Cooke A, Vaughan JI, Moore GE, Tolmie JL: U niparental isodisomy for chromosome 16 in a growthretarded infant with congenital heart disease. Prenat Diagn 1995; 15: 579-584.

27 Cattenach $B M$, Jones J: G enetic imprinting in the mouse: implication for gene regulation. J I nher M et D isease 1994; 17: $403-420$.
28 Cattenach B M, K irk M : D ifferential activity of maternally and paternally derived chromosome regions in mice. Nature 1985; 315: 496-498.

29 DeBry RW, Seldin MF: Human/M ouse homology relationships. Genomics 1996; 33: 337-351.

30 James R S, Temple IK, D ennis NR, Crolla JA : A search for uniparental disomy in carriers of supernumerary marker chromosomes. E ur J H um G enet 1995; 3: 21-26.

31 Kalousek DK, Langlois S, B arett I, Yam I, Wilson DR, Howard-Peebles PN, Johnson MP, Georgiutti E: U niparental disomy for chromosome 16 in humans. Am J H um G enet 1993; 52: 8-16.

32 Cassidy SB, Lai L-W, E rickson R P, M agnuson L, Thomas $E, G$ endron R, Herrmann J: Trisomy 15 with loss of the paternal 15 as a cause of Prader-Willi syndrome due to maternal disomy. A m J H um G enet 1992; 51: 701-708.

33 Robinson WP, Wagstaff J, Bernasconi F, Baccichetti C, A rtifoni $L$, Franzoni $E$, Suslak $L$, Shih $L-Y, A$ viv $H$, Schinzel A: Uniparental disomy explains the occurrence of A ngelman or Prader-Willi syndrome in patients with an additional small inv dup(15) chromosome. J M ed Genet 1993; 30: 756-760. 